\title{
Environmental Communication Strategy in Overcoming Cisadane River Water Pollution
}

\section{Strategi Komunikasi Lingkungan Dalam Mengatasi Pencemaran Air Sungai Cisadane}

\author{
Meisyanti $^{1}$, Khina Januar Rahmawati ${ }^{2}$ \\ ${ }^{1}$ Universitas Persada Indonesia Y.A.I, Jl. Pangeran Diponegoro No.74, Jakarta* \\ Email: meisyanti.hutagaol@gmail.com \\ ${ }^{2}$ Universitas Persada Indonesia Y.A.I, Jl. Pangeran Diponegoro No.74, Jakarta \\ Email: khina.januar@gmail.com
}

Masuk tanggal : 26-09-2020, revisi tanggal :05-01-2021, diterima untuk diterbitkan tanggal : 05-01-2021

\begin{abstract}
Water is the most important component for humans to maintain their life, but pollution also occurs in water. One of the rivers that have been polluted is the Cisadane River which stretches from West Java to Banten. This case of Cisadane River pollution is one of the cases included in the environmental communication study, where the role of the stakeholders in it is needed. The unity of purpose to overcome Cisadane River pollution can be done in various ways, one of them is by implementing an environmental communication strategy. The purpose of this study is to analyze and identify environmental communication strategies in handling Cisadane River pollution that have been carried out by the Government and the Environmental Service of Tangerang City and South Tangerang City and to develop environmental communication strategies to overcome the problem of Cisadane River pollution. The research method was using descriptive qualitative with data collection techniques interviews, observation and Focus Group Discussion (FGD). The results of this study indicate that the environmental communication strategy carried out by the Government and the Environmental Service of Tangerang City and South Tangerang City in terms of the communication component has been running well. To make it even better, it needs the consistency in the management of the environmental communication. The development of an environmental communication strategy model uses transformational communication features by adding several things to the strategies that have been implemented by the City Government and the Environmental Service of Tangerang City and South Tangerang City. For implementation this strategy, they need to monitor, evaluate and the synergy between the provincial, city government and the Environmental Service and other services in each area traversed by the Cisadane River.
\end{abstract}

Keywords: Cisadane river, environmental communication, strategy, water pollution

\begin{abstract}
Abstrak
Air menjadi komponen terpenting bagi manusia untuk mempertahankan kehidupannya, namun pencemaran juga terjadi pada air. Salah satu sungai yang tercemar adalah Sungai Cisadane yang terbentang dari Jawa Barat hingga Banten. Kasus pencemaran Sungai Cisadane ini merupakan salah satu kasus yang termasuk dalam kajian komunikasi
\end{abstract}


lingkungan, di mana dibutuhkan peran dari stakeholder yang di dalamnya. Kesatuan tujuan untuk mengatasi pencemaran Sungai Cisadane ini bisa dilakukan dengan berbagai cara, salah satunya dengan menjalankan strategi komunikasi lingkungan. Tujuan penelitian ini adalah untuk menganalisa dan mengidentifikasi strategi komunikasi lingkungan dalam penanganan pencemaran Sungai Cisadane yang sudah dilakukan oleh Pemerintah Kota dan Dinas Lingkungan Hidup Kota Tangerang dan Kota Tangerang Selatan dan untuk mengembangkan strategi komunikasi lingkungan untuk mengatasi masalah pencemaran Sungai Cisadane. Metode penelitian yang digunakan adalah deskriptif kualitatif dengan teknik pengumpulan data wawancara, observasi dan Focus Group Discussion (FGD). Hasil penelitian ini menyatakan bahwa strategi komunikasi lingkungan yang dijalankan oleh Pemerintah dan Dinas Lingkungan Hidup Kota Tangerang maupun Kota Tangerang Selatan ditinjau dari komponen komunikasi sudah berjalan dengan baik. Agar lebih baik lagi diperlukan konsistensi dalam pengelolaan strategi komunikasi lingkungan tersebut. Pengembangan model strategi komunikasi lingkungan menggunakan fitur komunikasi transformasional dengan menambahkan beberapa hal yang sudah dijalankan oleh Pemerintah Kota dan DLH Kota Tangerang dan Kota Tangerang Selatan. Dalam pelaksanaan strategi ini juga dibutuhkan monitoring, evaluasi dan perlu adanya sinergi antara pemerintah provinsi, kota maupun DLH dan dinas terkait lainnya pada setiap daerah yang dilintasi oleh Sungai Cisadane.

Kata Kunci : komunikasi lingkungan, pencemaran air, strategi, sungai Cisadane

\section{Pendahuluan}

Salah Satu fenomena yang terjadi saat ini adalah pencemaran air sungai yang kebanyakan didominasi oleh limbah baik dari rumah tangga maupun pabrik. Padahal air menjadi komponen terpenting bagi manusia untuk mempertahankan kehidupannya. Salah satu sumber air yang banyak digunakan masyarakat dan pemerintah sendiri untuk memperoleh air adalah sungai. Sungai dalam Peraturan Pemerintah Republik Indonesia Nomor 38 Tahun 2011 Tentang Sungai (2011) pasal 3, menyatakan bahwa sungai dikuasai oleh negara dan merupakan kekayaan negara. Pengelolaan sungai dilakukan secara menyeluruh, terpadu dan berwawasan ingkungan dengan tujuan untuk mewujudkan kemanfaatan fungsi sungai yang berkelanjutan.

Pengeloaan sungai adalah hal yang penting untuk dilakukan pemerintah, melihat bahwa sungai memiliki beberapa manfaat seperti untuk kebutuhan rumah tangga, pertanian, sanitasi lingkungan, industri, pariwisata, olahraga, pertahanan, perikanan, pembangkit tenaga listrik dan transportasi. Terkadang manfaat dari sungai ini juga sering menjadi sebab dari adanya pencemaran sungai, tentunya pencemaran sungai juga disebabkan oleh hal-hal lain yang berada di sekitar sungai tersebut.

Salah satu sungai yang tercemar adalah Sungai Cisadane yang terbentang dari Jawa Barat hingga Banten. Areal DAS Cisadane sendiri memiliki luas sebesar 151.808 ha, aliran sungai ini banyak dimanfaatkan oleh masyarakat yang bermukim di sekitar bantaran untuk memenuhi kebutuhan hidup sehari-hari dengan pola pemanfaatan yang beragam. Ada sekitar 246 industri di Kota Tangerang, diawasi Badan Pengendalian Lingkungan Hidup (BPLH) karena 
banyak dari industri itu yang membuang limbah cair dan limbah kimia B3 yang berbahaya ke Sungai Cisadane dan mencemari lingkungan (Dawud et al., 2016).

Pencemaran Sungai Cisadane terlihat dari penelitian tahun 2011 yang dilakukan oleh Ratna Siahaan, dkk menyimpulkan bahwa air Sungai Cisadane dari hulu hingga hilir telah tercemar. Kualitas air Sungai Cisadane dari hulu ke hilir semakin menurun, dan berdasarkan klasifikasi Miller, kualitas air Sungai Cisadane dari hulu hingga hilir yaitu tercemar ringan (Stasiun 1-6) dan tercemar parah di Stasiun 7-8 yang berada di bagian hilir. Secara umum, kualitas air Sungai Cisadane di bagian hulu dan tengah masih dapat dipergunakan sebagai air untuk peruntukan Kelas 2 dan di bagian hilir untuk peruntukan Kelas 3 dan 4 (Siahaan et al., 2011). Tahun 2014, kualitas air Sungai Cisadane terus memburuk akibat tercemar limbah mangan dan besi industri yang ada di sekitar Kota Tangerang, Banten, tidak hanya garmen, industri pertambangan juga turut mencemari air Sungai Cisadane (Beritasatu.tv, 2014).

Data lainnya terkait pencemaran air Sungai Cisadane yaitu mengutip dari Indopos.co.id pada bulan November 2018, pencemaran pada Sungai Cisadane didominasi oleh pencemar domestik (air limbah rumah tangga dan sampah) yang angkanya mencapai 83,99 persen, disusul pencemar industri (8,39 persen), pencemar peternakan (3,94 persen), pencemar pertanian (2,46 persen), pencemar prasarana dan jasa ( 0,71 persen) dan pencemar perikanan $(0,51$ persen) (Fatah, 2018). Selain itu pada Februari 2019, timbunan sampah Tempat Pembuangan Akhir (TPA) Cipeucang longsor dan mencemari Sungai Cisadane. Longsor terjadi akibat Sungai Cisadane yang meluap, dan menggerus hampir sekitar 11 ton sampah yang tidak terjaga pembatas di bibir TPA Cipeucang (Kurniawan, 2019).

Pencemaran sungai tentu tidak bisa dilepaskan dari peran Stakeholder yang berada di sekitar sungai tersebut, seperti Masyarakat, Pejabat Pemerintah Daerah, LSM, dll. Pencemaran Sungai Cisadane bukan berarti tidak ada tindakan yang dilakukan oleh pemerintah, namun tindakan ini butuh dukungan dari pihakpihak stakeholder lainnya agar pencemaran Sungai Cisadane bisa teratasi dengan baik. Terkait pencemaran lingkungan tentunya strategi yang digunakan adalah strategi komunikasi lingkungan. Komunikasi lingkungan adalah penggunaan pendekatan, prinsip, strategi dan teknik komunikasi untuk pengelolaan dan perlindungan lingkungan. Pada agenda program lingkungan, komunikasi menjadi bagian integral dari pengelolaan lingkungan di mana tanpa komponen komunikasi, bisa mengakibatkan pengelolaan lingkungan akan menghadapi masalah yang cukup krusial. Komunikasi lingkungan juga tidak harus berorientasi pada media tetapi harus bisa membangkitkan partisipasi masyarakat yang lebih besar, bahkan komunikasi harus mampu memberdayakan anggota masyarakat untuk bisa menjadi sumber informasi yang aktif (Flor \& Cangara, 2018). Sedangkan menurut Oepen and Hamacher (1999), Chox (2010) (dalam Lestari et al., 2016) komunikasi lingkungan adalah proses komunikasi terencana dan strategis yang digunakan produk media dalam mendukung pembuatan kebijakan efektif, partisipasi masyarakat dan pelaksanaan proyek yang diarahkan kepada kelestarian suatu lingkungan. Tujuan komunikasi lingkungan tentu bertujuan untuk menjaga dan meningkatkan peran dan kemampuan setiap stakeholder yang terkait untuk menjaga keberlangsungan dan kelestarian lingkungan tersebut. 
Tujuan ini bisa dilakukan dengan berbagai cara, salah satunya dengan menjalankan strategi komunikasi lingkungan.

Strategi komunikasi adalah kiat atau taktik yang dapat dilaksanakan dalam perencanaan komunikasi (Astuti et al., 2016). Menurut Effendy (dalam Frianda et al., 2018) strategi komunikasi adalah panduan dari perencanaan komunikasi (communication planning) dan manajemen komunikasi (communication management) untuk mencapai tujuan. Menurut Middleton (dalam Cangara, 2013) strategi komunikasi merupakan kombinasi terbaik dari semua elemen komunikasi mulai dari komunikator, pesan, saluran penerima sampai pengaruh yang dirancang untuk mencapai tujuan komunikasi optimal. Dalam strategi komunikasi terdapat komponen komunikasi, yaitu (1) Komunikator, (2) Pesan Komunikasi, (3) Media Komunikasi, dan (4) Khalayak Sasaran, (Situmeang, 2020). Pada penelitian yang dilakukan oleh Frianda, dkk menggunakan empat komponen strategi komunikasi yang terdiri dari pesan, media, penerima dan efek (Frianda et al., 2018). Sedangkan untuk penelitian ini menggunakan empat komponen yaitu, komunikator, pesan, media dan penerima di mana keempat komponen ini digunakan untuk menganalisis strategi komunikasi lingkungan yang sudah dilakukan oleh pihak terkait dalam mengatasi pencemaran air Sungai Cisadane.

Seiring jalannya waktu dibutuhkan pengembangan strategi komunikasi lingkungan yang relevan dengan situasi dan kondisi, maka untuk mendapatkan model strategi komunikasi lingkungan yang dapat mengatasi pencemaran air Sungai Cisadane, penelitian ini juga merujuk pada fitur komunikasi transformasional yang terdiri dari multilevel/multisektoral di mana komunikasi lingkungan harus dilakukan pada semua tingkat masyarakat. Selanjutnya fitur yang berorientasi pada proses dengan sinergitas, yaitu komunikator mengambil peran sebagai fasilitator dan katalisator melalui pengaturan agenda sosial, pembentukan opini publik, dan mobilisasi masyarakat. Fitur berikutnya adalah strategis, yakni komunikasi lingkungan difokuskan pada pemain kunci tertentu dalam proses-proses sosial atau kelembagaan masyarakat (Flor \& Cangara, 2018). Pada multi-level terdapat komponen media, informasi, pendidikan dan mobilisasi sosial. Berorientasi proses, dengan menggunakan proses AIDA, sinergi-driven dengan mengerjakan bauran media dan multi-sektoral melibatkan beberapa khalayak/mitra kerja sama yang mencakup stakeholder. Kemudian strategis dilakukan melalui saluran interpersonal, kelompok, jaringan kelembagaan dan media (Flor \& Cangara, 2018). Selain itu penelitian ini juga merujuk pada penelitian yang dilakukan oleh Aulira, dkk mengenai delapan langkah komunikasi lingkungan yang ditemukan dari Wahyudin, yaitu menganalisis situasi dan masalah, melakukan analisis pada pihak/pelaku yang terlibat pada kasus, komunikasi untuk meningkatkan pengetahuan dan memengaruhi perilaku, pengembangan strategi komunikasi, memotivasi dan memobilisir masyarakat, pemilihan media yang digunakan, penyebaran melalui media dan implementasinya dan proses dokumentasi, monitoring dan evaluasi (Tan et al., 2019). 
Dalam penelitian ini teori yang digunakan adalah teori Perencanaan Komunikasi yang ditulis oleh Charles R. Berger, pada teori ini menjelaskan bagaimana individu tiba pada pemahaman mengenai tindakan dan pembicaraan terhadap satu sama lain dengan tujuan yang diarahkan, dan bagaimana individu menghasilkan tindakan dan pembicaraan yang memungkinkan mereka mencapai tujuan (Budyatna, 2015). Untuk menjalankan strategi komunikasi dibutuhkan perencanaan, peran penting dan kerjasama para individu yang merupakan stakeholder terkait. Stakeholder perlu dilibatkan dalam bentuk strategi komunikasi lingkungan agar mendapatkan pemahaman, menghasilkan tindakan dan pembicaraan yang sesuai dengan tujuan strategi komunikasi lingkungan yaitu dalam hal ini untuk mengatasi pencemaran air Sungai Cisadane.

Berdasarkan uraian di atas maka rumusan masalah yang diteliti adalah Bagaimana strategi komunikasi lingkungan dalam penanganan pencemaran air Sungai Cisadane yang sudah dilakukan oleh Pemerintah Kota dan Dinas Lingkungan Hidup baik Kota Tangerang maupun Kota Tangerang Selatan? Dan bagaimana pengembangan strategi komunikasi lingkungan yang dapat digunakan untuk mengatasi masalah pencemaran air Sungai Cisadane?. Adapun penelitian ini memiliki dua tujuan penelitian yaitu untuk menganalisa dan mengidentifikasi strategi komunikasi lingkungan dalam penanganan pencemaran air Sungai Cisadane yang sudah dilakukan oleh oleh Pemerintah Kota dan Dinas Lingkungan Hidup Kota Tangerang dan Kota Tangerang Selatan dan untuk mengembangkan strategi komunikasi lingkungan untuk mengatasi masalah pencemaran air Sungai Cisadane.

\section{Metode Penelitian}

Penelitian ini menggunakan metode pendekatan kualitatif deskriptif di mana penelitian kualitatif lebih menekankan kepada persoalan kedalaman data dan bukan banyaknya data (Kriyantono, 2012). Pendekatan kualitatif memiliki asumsi metodologi yaitu proses induktif, terus-menerus mempertajam penjelasan, desain riset terus berkembang selama riset, memperhatikan konteks, mencari pola dan membangun teori, verifikasi-triangulasi (Imran, 2015). Sedangkan deskriptif bertujuan membuat deskripsi secara sistematis, faktual, dan akurat tentang fakta dan sifat populasi atau objek tertentu (Kriyantono, 2012).

Data penelitian ini terdiri dari data primer yaitu data yang dapat diperoleh langsung dari objek penelitian dan data sekunder adalah data yang didapatkan dari literatur, dokumentasi dan informasi yang terkait dengan masalah penelitian (Tunggala \& Saadjad, 2019). Dalam penelitian ini yang menjadi subjek penelitian adalah Pemerintah dan Dinas Lingkungan Hidup (DLH) Kota Tangerang dan Kota Tangerang Selatan, Aktivis Lingkungan Hidup, YAPELH Indonesia dan Masyarakat RW.03 Kelurahan Karawaci. Sedangkan yang menjadi objek penelitiannya adalah pencemaran air Sungai Cisadane di Kota Tangerang dan Kota Tangerang Selatan. Dalam pengumpulan data, teknik yang peneliti gunakan adalah wawancara, observasi dan Focus Group Discussion (FGD). Peneliti melakukan observasi pada jenis media yang digunakan untuk mengatasi pencemaran air Sungai Cisadane, dan wawancara dilakukan pada pihak 
Pemerintah dan Dinas Lingkungan Hidup (DLH) Kota Tangerang dan Kota Tangerang Selatan, Aktivis Lingkungan Hidup, dan YAPELH Indonesia. Sedangkan Focus Group Discussion (FGD) adalah teknik pengumpulan data yang dilakukan dengan wawancara mendalam dalam suatu kelompok, di mana dalam pertemuan kelompok tersebut menggambarkan karakteristik yang ditentukan dalam usulan, ukuran, komposisi dan prosedur wawancara (Mishra, 2016). FGD dilakukan pada Masyarakat RW.03 Kelurahan Karawaci dengan teknik purposive sampling. Dalam menganalisa data, peneliti menggunakan teknik analisa data model Miles dan Huberman. Data yang sudah diperoleh kemudian dikaji lalu dilakukan klasifikasi sesuai dengan jenis data, setelah itu dianalisis sehingga diperoleh kesimpulan (Fida et al., 2019).

\section{Hasil Penemuan dan Diskusi}

Penelitian ini berfokus pada penanganan pencemaran air Sungai Cisadane ditinjau dari daerah Kota Tangerang dan Kota Tangerang Selatan, di mana dua daerah ini tentunya memiliki peranan penting dalam menjaga kebersihan dari Sungai Cisadane. Peneliti menemukan bahwa Pemerintah dan Dinas Lingkungan Hidup (DLH) Kota Tangerang dan Kota Tangerang Selatan sudah melakukan upaya-upaya komunikasi untuk mengatasi pencemaran air Sungai Cisadane. Namun, tetap diperlukan langkah-langkah strategis dan sinergi antara semua stakeholder yang berkaitan.

Dari wawancara yang dilakukan oleh peneliti dengan Bapak Djarkasih selaku Kepala Seksi Pemantauan Kualitas Lingkungan DLH Kota Tangerang didapatkan bahwa hasil penelitian yang dilakukan oleh Dinas Lingkungan Hidup Kota Tangerang diketahui pencemaran yang terjadi di Sungai Cisadane bagian Kota Tangerang berada pada kategori cemar ringan sampai sedang. Di mana pencemaran terjadi dikarenakan adanya limbah domestik yang rata-rata disebabkan oleh detergen.

Sedangkan Sungai Cisadane yang mengalir di daerah Kota Tangerang Selatan menurut hasil wawancara dengan Kepala Seksi Pemantauan Kualitas Lingkungan DLH Kota Tangerang Selatan, Ibu Laily, tingkat pencemarannya adalah cemar ringan ke cemar berat dan lebih banyak disebabkan oleh limbah domestik. Hal ini sesuai dengan penelitian yang dilakukan oleh Ratna Siahaan, dkk bahwa Sungai Cisadane telah tercemar (Siahaan et al., 2011) dan hasil ini sesuai juga dengan pemberitaan pada Indopos.co.id pada tahun 2018 yang menyatakan bahwa pencemaran di Sungai Cisadane didominasi oleh pencemar domestik (air limbah rumah tangga dan sampah) yang angkanya mencapai 83,99 persen (Fatah, 2018).

Melihat tingkat pencemaran air di Sungai Cisadane baik dari Kota Tangerang maupun Kota Tangerang Selatan, maka diperlukan langkah strategis pada masing-masing daerah tersebut untuk mengatasi pencemaran. Komunikasi dengan dinas-dinas yang terkait Sungai Cisadane dan juga terutama komunikasi kepada masyarakat ataupun stakeholder lainnya menjadi salah satu hal yang perlu dijalankan sehingga bisa terjadi sinergi yang baik. Untuk menjalankan komunikasi lingkungan dapat dilihat dari komponen komunikasi yang menjadi kajian dalam 
strategi komunikasi, yaitu komunikator, pesan komunikasi, media komunikasi, dan khalayak sasaran.

\section{Analisis Strategi Komunikasi Lingkungan yang Dilakukan oleh Kota Tangerang dan Kota Tangerang Selatan dalam Mengatasi Pencemaran Air Sungai Cisadane}

a. Komunikator

Dalam pelaksanaannya strategi komunikasi lingkungan ditinjau dari komponen komunikator dapat dijelaskan pada tabel di bawah ini :

Tabel 1. Komunikator yang Digunakan

\begin{tabular}{ll}
\hline \multicolumn{1}{c}{ Nama Daerah } & \multicolumn{1}{c}{ Komunikator } \\
\cline { 2 - 3 } Kota Tangerang & Pemerintah Kota \\
& Dinas Lingkungan Hidup \\
& Ketua RT \\
& Ketua RW \\
& Kader Lingkungan tiap lingkungan masing-masing \\
& Narasumber Ahli \\
& Komunitas Lingkungan (Bank Sampah, dll) \\
& Dan Komunikator lainnya \\
Kota Tangerang Selatan & Pemerintah Kota \\
& Dinas Lingkungan Hidup \\
& Ikon Pelitas (Penyelamat Lingkungan Tangerang \\
& Selatan) \\
& Komunitas Peduli Lingkungan dan Bank Sampah \\
& Tokoh Agama \\
& RT dan RW Setempat \\
& Tokoh Masyarakat lainnya \\
& Dan Komunikator lainnya \\
&
\end{tabular}

Di Kota Tangerang, Pemerintah Kota dan Dinas Lingkungan Hidup menjadi komunikator, yang kemudian mereka memilih para komunikator lainnya seperti Ketua RT, Ketua RW dan kader lingkungan. Para komunikator ini diberikan edukasi dan sosialisasi sebelumnya oleh Pemerintah Kota Tangerang maupun Dinas Lingkungan Hidup Kota Tangerang sebelum terjun ke masyarakat. Seperti yang diketahui untuk menjadi komunikator yang baik diperlukan daya tarik dan kredibilitas (Situmeang, 2020), sehingga dengan menarik tokoh terdekat dengan masyarakat dan memberikan sosialisasi sebelumnya dapat menjadikan mereka komunikator yang baik. Tokoh-tokoh tersebut juga menjalankan edukasi kepada masyarakat, hal ini dirasa lebih efektif jika dibandingkan menunjuk satu orang sebagai duta.

"Sarana edukasi yang melakukan adalah petugas LH nya, kedua RT RW, ketiga komunitas. Lebih efektif jika kita langsung aja ke masyarakat, keliling, libatin RT $R W$, komunitas meskipun kondisinya kaya sekarang kurang efektif juga, namun jauh lebih efektif dibanding hanya sekedar nunjuk seseorang jadi duta sampah terus kemudian dia jadi pion karena kurang masif kan" (Bapak Mualim - Kepala Bidang Diseminasi Informasi dan Komunikasi Publik Kota Tangerang) 
Untuk petugas Lingkungan Hidup dan narasumber ahli biasanya untuk mengisi penyuluhan, sosialisasi ataupun webinar yang digunakan saat pandemi seperti ini. Petugas Lingkugan Hidup selain memberikan penyuluhan dan sosialisasi juga langsung terjun ke lapangan untuk memantau program-program yang tengah dijalankan oleh Dinas Lingkungan Hidup Kota Tangerang. Sedangkan untuk komunitas lingkungan di Kota Tangerang cukup banyak jumlahnya, mereka juga melakukan edukasi kepada masyarakat terutama dalam menjaga kebersihan Sungai Cisadane, salah satu komunitas tersebut adalah Banksasuci (Bank Sampah Sungai Cisadane). Banksasuci merupakan komunitas aktif dalam hal kebersihan Sungai Cisadane dan mereka fokus pada pengelolaan sampah.

Dalam memilih komunikator, Kota Tangerang Selatan selain menggunakan komunikator Pemerintah Kota dan Dinas Lingkungan Hidup juga menggunakan karakter Pelitas yang merupakan singkatan dari Penyelamat Lingkungan Tangerang Selatan. Karakter ini dipilih sebagai sarana pendidikan bagi anak-anak, dengan harapan anak-anak dapat memelihara lingkungan sedari dini.

"Telah dilakukan pembuatan karakter pelitas, dimana media ini untuk dipergunakan dalam bidang pendidikan, sehingga anak-anak dapat memelihara lingkungan sedari dini” (Bapak Irfan Santoso - Kepala Bidang Kehumasan Diskominfo Kota Tangerang Selatan)
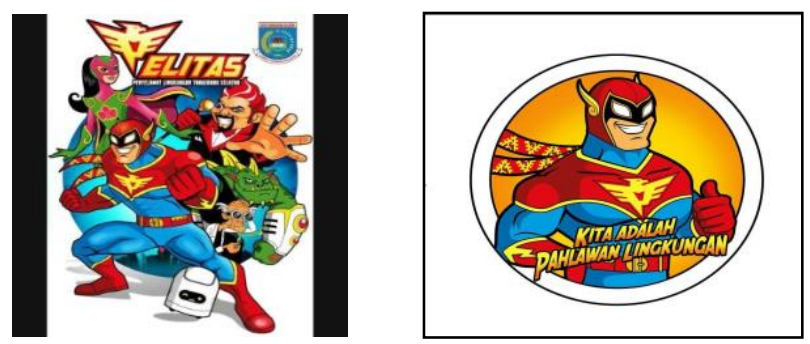

Gambar 1: Pelitas (Sumber: Kabartangsel.com \& Instagram @ dlhtangsel)

Selain karakter Pelitas, Kota Tangerang Selatan juga memilih komunitas peduli lingkungan dan bank sampah sebagai komunikator guna menyampaikan sosialisasi kepada masyarakat sekitar, komunitas tersebut antara lain Ganespa, Sekber Jeletreng, dan lain-lain. Komunitas tersebut merupakan komunitas yang terbentuk berdasarkan sosialisasi yang dilakukan pemerintah kepada masyarakat secara intens. Komunitas ini tentunya diberdayakan dalam hal pengelolaan sampah di Kota Tangerang Selatan. Tokoh agama, RT dan RW serta tokoh masyarakat lainnya juga turut ditunjuk sebagai komunikator untuk mensosialisasikan kepada masyarakat.

\section{b. Pesan Komunikasi}

Pesan adalah suatu hal yang disampaikan oleh komunikator kepada khalayak sasaran dan memiliki tujuan tertentu (Situmeang, 2020). Dari wawancara dan observasi yang dilakukan peneliti maka didapatkan hasil bahwa pesan komunikasi yang digunakan oleh Pemerintah dan Dinas Lingkungan Hidup 
Meisyanti, Khina Januar Rahmawati:

Environmental Communication Strategy in Overcoming Cisadane River Water Pollution

Strategi Komunikasi Lingkungan Dalam Mengatasi Pencemaran Air Sungai Cisadane

Kota Tangerang maupun Pemerintah dan Dinas Lingkungan Hidup Kota Tangerang Selatan adalah pesan yang bersifat ajakan dan pesan bersifat ganjaran yang disertai dengan gambar maupun video yang mendukung pesan tersebut. Kedua sifat pesan komunikasi bertujuan agar masyarakat dapat berpartisipasi dalam kegiatan dan program yang dilakukan oleh Kota Tangerang dan Kota Tangerang Selatan, karena pemberdayaan masyarakat sangat perlu dilakukan dalam mengatasi pencemaran air di Sungai Cisadane.

Pencemaran air di Sungai Cisadane paling banyak disebabkan oleh limbah domestik yang terdiri dari sampah dan air limbah rumah tangga. Dalam penanganan sampah baik Kota Tangerang dan Kota Tangerang Selatan sama-sama menggerakan bank sampah di mana bank sampah ini merupakan suatu tempat yang di mana sampah dari rumah tangga yang sudah dipisahkan ataupun belum akan diproses di tempat ini sehingga tidak semua sampah tersebut akan masuk ke Tempat Pembuangan Akhir (TPA). Sampah-sampah yang masih dapat dimanfaatkan misal sampah an-organik akan dijual ataupun di-recycle menjadi barang yang berguna, sedangkan yang organik dapat dijadikan pupuk kompos untuk tanaman baru kemudian residunya dibuang ke TPA.

"Ya kalau sifatnya ajakan itu pasti. Yang pasti kita rujukannya kepada peraturan perundangan-undangan, misalnya sampah itu kan sifatnya ada aturan tersendiri. Terus kalau ajakannya yang sifatnya ekonomis, misal satu $R W$ ada bank sampah yang sifatnya ekonomis kan bisa masuk ke pos $R W$, masuk ke bank sampah. Sifatnya yang bernilai ekonomis itu untuk yang an-organik, kalau yang sifatnya organik kita buat kompos, pupuk cair minimal buat mereka jugalah untuk tanaman mereka, pasti ajakan selalu kita ajak terus." (Bapak Djarkasih - Kepala Seksi Pemantauan Kualitas Lingkungan DLH Kota Tangerang)

"Sebenarnya yang sudah dilakukan dari segi informasi untuk masyarakat, anak kecil, sampai orang tua, ada pembentukan bank sampah, $3 R$, itu sudah berjalan semua tapi memang belum optimal mengatasi permasalahan sampah yang ada di Tangsel." (Ibu Laily - Kepala Seksi Pemantauan Kualitas Lingkungan DLH Kota Tangerang Selatan)

Pemerintah berusaha untuk memberikan pesan ajakan dengan tujuan masyarakat dapat melakukan pemilahan sampah dari rumah masing-masing sehingga masyarakat dapat memanfaatkan sampahnya untuk dijadikan uang. Pesan ini diharapkan dapat memengaruhi masyarakat agar bisa mengurangi jumlah sampah yang dibuang ke Tempat Pembuangan Akhir (TPA), Pemerintah Kota dan Dinas Lingkungan Hidup (DLH) juga menyediakan bank-bank sampah untuk membantu masyarakat dalam mengelola sampah tersebut. Selain itu melalui media sosial masing-masing kota baik melalui media sosial milik pemerintah ataupun dinas, juga turut memberikan pesan-pesan yang selalu menghimbau masyarakat untuk tetap menjaga lingkungan, pesan tersebut pun dikemas dengan dukungan visual yang menarik. 


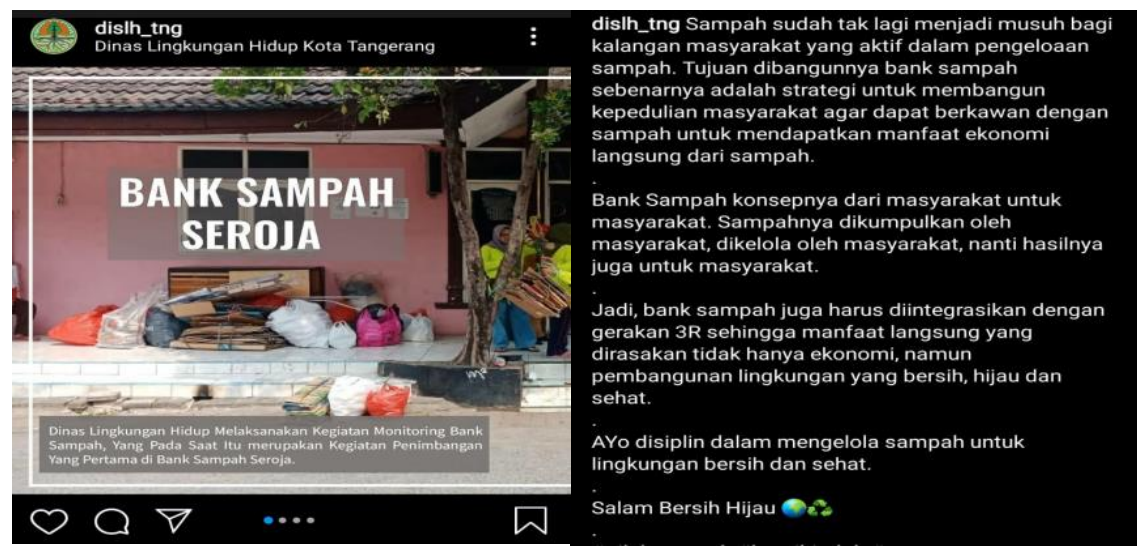

Gambar 2: Pesan Komunikasi Kota Tangerang

(Sumber : Instagram @ dislh_tng)

Selain pesan yang bersifat ajakan, pemerintah dan Dinas Lingkungan Hidup juga menggunakan pesan yang bersifat ganjaran. Seperti pada gambar di atas, beberapa pesan untuk mengelola sampah yang diberikan oleh pemerintah dan dinas di dalamnya juga mengandung ganjaran. Contohnya yang dilakukan oleh Pemerintah dan Dinas Lingkungan Hidup Kota Tangerang yang menggalakan suatu program dengan di dalamnya ada ganjaran yang akan didapat oleh masyarakat jika melakukannya.

Di Kota Tangerang Selatan, pesan ganjaran yang diberikan Pemerintah dan Dinas Lingkugan Hidup juga menggunakan sistem yang sama dengan harapan adanya kontribusi masyarakat dalam menjaga lingkungan, di mana informasi tersebut sudah dilakukan kepada anak kecil sampai orang tua. Dengan tersedianya bank sampah, pemerintah dan dinas terus menggalakan dan memperkenalkan bank sampah agar masyarakat dapat memilah sampah rumah tangga masingmasing. Ketika selesai memilah sampah dan diberikan kepada bank sampah, masyarakat juga bisa mendapatkan keuntungan dari hasil penjualan tersebut. Misalnya pada tahun 2019 lalu beberapa bank sampah di Kota Tangerang Selatan melakukan donasi yang diberikan untuk korban tsunami Banten, tentunya dengan adanya program dengan keuntungan seperti ini membuat tujuan komunikasi dari pemerintah dan dinas dapat tercapai dengan baik.

Pemerintah juga merangkul komunitas untuk bisa menyampaikan pesan tersebut kepada masyarakat di sekitar komunitas tersebut. Pada dasarnya pesan komunikasi perlu tetap terus dijalankan baik yang bersifat persuasif maupun yang bersifat ganjaran. Sehingga pemberdayaan masyarakat dapat terjadi dan bisa terjalin kerjasama antar pemerintah, dinas, masyarakat, komunitas bahkan stakeholder lainnya untuk menjadikan Sungai Cisadane terbebas dari pencemaran. 
Meisyanti, Khina Januar Rahmawati:

Environmental Communication Strategy in Overcoming Cisadane River Water Pollution

Strategi Komunikasi Lingkungan Dalam Mengatasi Pencemaran Air Sungai Cisadane

c. Media Komunikasi

Dalam menangani pencemaran air di Sungai Cisadane, media yang digunakan antara lain :

Tabel 2. Media yang Digunakan

\begin{tabular}{cll}
\hline \multirow{3}{*}{$\begin{array}{c}\text { Nama Daerah } \\
\text { Kota Tangerang Selatan }\end{array}$} & \multicolumn{1}{c}{ Media Tradisional } & \multicolumn{1}{c}{ Media Digital } \\
\cline { 2 - 3 } & Billboard & Website \\
& Tatap Muka (Sosialisasi) & Media Sosial (Facebook, \\
& & Twitter, Instagram, \\
& & Youtube) \\
& & Aplikasi (SIPALI, \\
& & SIARAN Tangsel, dll) \\
Kota Tangerang & E- Kliping (Media Online \\
& & Harian Pemerintah Kota \\
& & Tangerang Selatan) \\
& Koran Benteng & dll \\
& Tabloid & Website \\
& Brosur & Media Sosial (Facebook, \\
& Baliho & Twitter, Instagram, \\
Tatap Muka (Sosialisasi,, & Youtube) \\
& Aplikasi (Tangerang Live - \\
& Lenong, dll) & LAKSA) \\
dll & Aplikasi di Website DLH \\
& Kota Tangerang (Green \\
& dan SIL) \\
& Kota Tangerang E-Paper \\
& (Live Magazine, Kota \\
& Benteng, Buletin) \\
& Webinar \\
& dll \\
&
\end{tabular}

Seperti pada tabel di atas berdasarkan wawancara dan observasi yang peneliti lakukan, penggunaan media di Kota Tangerang dan Kota Tangerang Selatan untuk menyebarkan pesan komunikasi yang ditujukan kepada masyarakat menggunakan media tradisional dan media digital dengan konten yang dapat dipahami oleh masyarakat.

Pemakaian media tradisional masih tetap digunakan, karena melihat bahwa tidak semuanya masyarakat terbiasa dengan digital sehingga semua masyarakat seharusnya mendapatkan pesan tersebut. Media tradisional berupa tatap muka biasanya dipakai saat ada kegiatan sosialisasi, edukasi kepada masyarakat, tatap muka dirasa tetap menjadi media yang paling efektif untuk melakukan kegiatan sosialisasi dan edukasi kepada masyarakat, bahkan kegiatan seperti lenong juga turut menjadi media tatap muka untuk menyampaikan pesan komunikasi kepada masyarakat. Media tatap muka juga dipakai oleh komunitas lingkungan dalam melakukan edukasi dan membangun hubungan dengan masyarakat. Media tradisional lainnya seperti media cetak berupa koran dan tabloid cetak serta brosur juga masih menjadi andalan sebagai media penyampai pesan. Selain itu media tradisional lainnya adalah billboard dan baliho yang 
dipasang di beberapa titik jalan, tentunya media ini dapat digunakan sebagai penyampai pesan.

Berdasarkan hasil observasi, media digital yang digunakan Pemerintah dan Dinas Lingkungan Hidup Kota Tangerang Selatan dalam penyampaian pesan atau informasi adalah website www.tangerangselatankota.go.id, dlh.tangerangselatankota.go.id dan website dinas-dinas lainnya, media sosial Facebook Fanspage @ humaskotatangsel, dan Facebook Dinas Lingkungan Hidup Kota Tangerang Selatan,Twitter @humastangsel dan@dlhtangsel, Instagram @humaskotatangsel dan @dlhtangsel dan Youtube Humas Kota Tangerang Selatan, termasuk media sosial dinas-dinas lainnya yang terkait. Perkembangan teknologi membuat pemerintah dan DLH memanfaatkan media sosial untuk bisa menjangkau khalayak dengan tema pesan lingkungan dan lainnya.
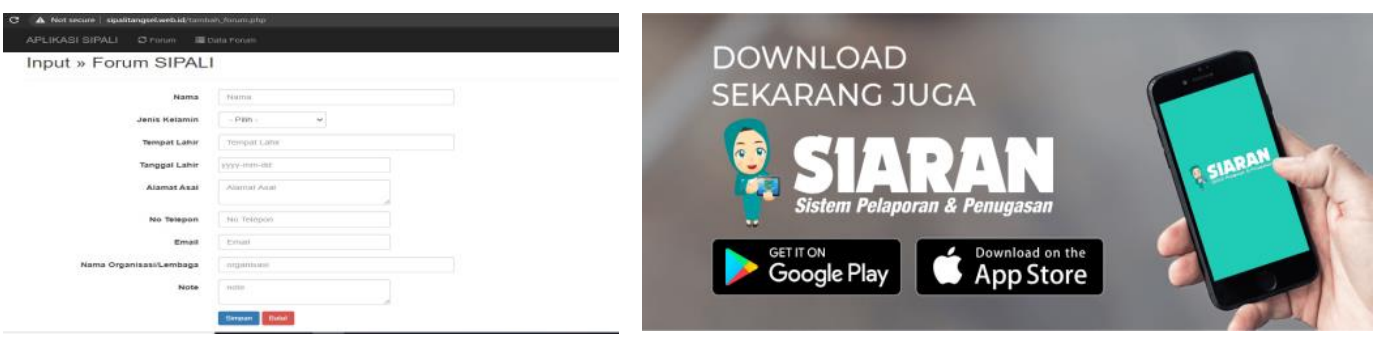

Gambar 3: Aplikasi SIPALI dan SIARAN Tangsel

(Sumber : www.sipalitangsel.web.id dan www.siaran.tangerangselatankota.go.id)

Selain website dan media sosial, pada Kota Tangerang Selatan juga terdapat aplikasi yang dapat digunakan masyarakat untuk mendapatkan informasi ataupun untuk melaporkan sesuatu hal yang berkaitan dengan lingkungan dari Kota Tangerang Selatan termasuk di dalamnya jika ingin melaporkan pencemaran di Sungai Cisadane. Aplikasi tersebut adalah SIPALI (Sistem Integrasi Data Pemantauan Kualitas Lingkungan Kota Tangerang Selatan) dan SIARAN Tangsel (Sistem Pelaporan dan Penugasan). Selain itu Pemerintah Kota Tangerang Selatan dalam menyampaikan informasi adalah E- Kliping (Media Online Harian Pemerintah Kota Tangerang Selatan) dan media digital lainnya.

Pada Kota Tangerang, media digital yang digunakan adalah website www.tangerangkota.go.id, dislh.tangerangkota.go.id dan website dinas lainnya. Untuk media sosial yang digunakan adalah Facebook Pemerintah Kota Tangerang, Humas Kota Tangerang dan DLH_Kota Tangerang, Twitter @Kota_Tangerang, @HumasTangerang dan @ dislh_Tng, Instagram @ tangerangkota, @humas_kota_tangerang dan @dislh_tng, Youtube Kota Tangerang (Tangerang Tv) dan DLH Kota Tangerang, selain itu juga terdapat media sosial dinas-dinas lainnya yang terkait. Sama seperti di website, kegiatankegiatan yang dilakukan oleh pemerintah dan Dinas Lingkungan Hidup juga dibagikan melalui media sosial ini, misalnya mengenai sampah, program-program yang sedang dijalankan oleh pemerintah kota ataupun DLH, dan lain-lain. 
Pemerintah Kota Tangerang juga memiliki aplikasi yang bernama Tangerang Live di mana di dalamnya juga terdapat aplikasi LAKSA (Layanan Aspirasi Kotak Saran Anda) yaitu aplikasi untuk menyampaikan pengaduan dan saran dari masyarakat mengenai suatu hal yang ada di lingkup Kota Tangerang. Dengan adanya aplikasi LAKSA ini juga dapat mendorong masyarakat untuk aktif, salah satunya juga dengan bisa memberikan laporan dan saran mengenai Sungai Cisadane. Selain itu hasil observasi peneliti menunjukkan terdapat menu aplikasi pada website DLH Kota Tangerang, yaitu Green dan SIL (Sistem Informasi Lingkungan) Dinas Lingkungan Hidup Kota Tangerang. Aplikasi Green adalah aplikasi pengelolaan sampah, di mana di dalamnya terdapat data pengelolaan sampah, data detail pengurangan sampah, penanganan sampah dan volume sampah masuk TPA. Sedangkan SIL (Sistem Informasi Lingkungan) terdiri dari fitur MONIKUR (Monitoring Kualitas Udara), DOKULING (Dokumen Lingkungan), MONIKAR (Monitor Kualitas Air), APRILIA (Aplikasi Pelaporan Hasil Kajian Ilmiah), ASEPAK (Aplikasi Sebaran Dampak), Bank Pohon dan PLC (Aplikasi Perizinan Limbah Cair). Fitur MONIKAR (Monitor kualitas Air) dapat digunakan untuk melihat kualitas air Sungai Cisadane dan anak sungai yang berada di Kota Tangerang.

Media digital lainnya yang digunakan oleh Kota Tangerang adalah Kota Tangerang E-Paper yang terdiri dari Live Magazine, Kota Benteng dan Buletin dengan berbentuk digital. Tentunya dengan hadirnya majalah, koran dan buletin versi digital ini lebih memudahkan masyarakat dalam mengetahui informasiinformasi yang dapat disajikan lebih panjang dan detail. Di masa pandemic Covid-19, Pemerintah Kota Tangerang juga menggunakan webinar sebagai media. Selain itu Dinas Lingkungan Hidup (DLH) juga pernah melakukan pelatihan pengembangan kapasitas pengelolaan lingkungan hidup secara online dengan menggunakan fitur live di Instagram dan Youtube.

\section{d. Khalayak Sasaran}

Pada pengaplikasian strategi komunikasi lingkungan dalam mengatasi pencemaran air Sungai Cisadane, yang menjadi khalayak sasaran adalah masyarakat Kota Tangerang dan Kota Tangerang Selatan, industri, pengembang dan komunitas lingkungan. Dalam hal ini komunitas juga bisa menjadi komunikator sebagai mitra pemerintah kota dan Dinas Lingkungan Hidup (DLH) untuk menjangkau masyarakat.

Masyarakat menjadi salah satu stakeholder yang penting dalam pengaplikasikan strategi komunikasi lingkungan ini. Seperti yang diketahui bahwa salah satu penyebab terbesar pencemaran air Sungai Cisadane berasal dari limbah domestik seperti sampah, limbah rumah tangga, dan lain-lain. Pencemaran air Sungai Cisadane sendiri sebenarnya sudah berkurang dari tahun-tahun sebelumnya. Dahulu di bantaran Sungai Cisadane masih terdapat pemukiman warga, sehingga tidak hanya sampah dan limbah rumah tangga namun juga terdapat limbah yang mengandung bakteri total coliform (Ecoli yang dari tinja). Namun setelah diberikan edukasi dan sosialisasi maka limbah yang mengandung bakteri total coliform ini sudah dapat diatasi dengan pembuatan septic tank. Di 
Kota Tangerang sendiri telah memasang turap di setiap bibir Sungai Cisadane sehingga tidak ada lagi bangunan liar yang berada di pinggir Sungai Cisadane.

Perlunya pemahaman masyarakat dalam menjaga lingkungan perlu terus dilakukan, masyarakat yang berada di sekitar YAPELH Indonesia yang di dalamnya terdapat Banksasuci pada awalnya belum terlalu mengalami dampak dari adanya pemilahan sampah, lingkungan yang bersih namun lambat laun dengan adanya komunikasi yang terus menerus dijalankan, sosialisasi dan edukasi maka sudah mulai ada perubahan perilaku.

"Kita tetap lakukan penelusuran jalan sambil kita rapih-rapih, bersih-bersih, sosialisasi ke masyarakat, jalin hubungan dengan mereka untuk menjadi saudara. Akhirnya kita ada basecamp juga di atas, ada beberapa saung yang kemudian jadi saudara kita (Banksasuci). 4 tahun melakukan komunikasi dengan RT dan RW nya, kita kasih pohon ke situ, kita ngobrol lagi, kita ada rejeki apalagi kita kasih ke situ, kita kasih spanduk. Tahun yang ke-4 barulah mereka berubah, mereka bikin saung, bikin taman-taman di situ dan tempat sampahnya, nah itu kan komunikasi perubahan perilaku." (Uyus Setia Bhakti-Direktur Eksekutif YAPELH Indonesia)

Masyarakat selain memerlukan informasi lengkap juga perlu disertakan dalam suatu kegiatan dan pengembangannya. Dengan hal ini maka mereka akan jauh lebih terlibat dalam bertindak dibandingkan ketika hanya diberikan informasi atau tanggung jawab terbatas, seperti yang dikatakan dalam Jasanoff \& Wynne (Brulle, 2010). Anggota masyarakat harus bisa diberdayakan untuk bisa menjadi sumber informasi yang aktif melalui komunikasi (Flor \& Cangara, 2018)

Selain itu untuk dapat menggerakan masyarakat diperlukan pesan yang mudah dimengerti oleh masyarakat, diperlukan bahasa yang sama antar komunikator dengan khalayak sehingga proses edukasi juga mudah dilakukan.

"Nah prosedur birokrasi seperti itu, masyarakat juga tidak tau jadi 2 orang yang mau pdkt tapi bahasanya beda yang satu pakai bahasa daerah mana, yang satu pakai bahasa daerah mana sehingga tidak nyambung. Masyarakat hanya bisa melaporkan dengan cara yang sudah tersistem jadinya kita bisa mengedukasi masyarakat dengan bahasa yang sama sehingga sudah dibaca dengan bahasa yang semua orang bisa relate." (Mikhail Gorbachev Dom - Environmental Scientist \& Disaster Management Research Unit CSIS)

Pentingnya pesan dan cara menyampaikan yang baik memang perlu menjadi perhatian bagi setiap komunikator agar khalayak masyarakat ini bisa memahami dan bisa memiliki keinginan untuk terjun dalam menjaga lingkungan terutama Sungai Cisadane. Di Kota Tangerang Selatan, masyarakat diberdayakan dalam hal pengelolaan sampah sehingga terbentuk bank sampah, TPS 3R dan komunitas peduli lingkungan seperti Ganespa, Sekber Jeletreng, dan lain-lain. Masyarakat juga diberi tanggung jawab dalam hal pengelolaan limbah yang dihasilkan baik limbah cair maupun limbah padat.

Peneliti melakukan Focus Group Discussion (FGD) pada masyarakat RW.03 Kelurahan Karawaci-Kota Tangerang, masyarakat yang tinggal dekat dengan Sungai Cisadane. Masyarakat setempat menyatakan bahwa programprogam dari Pemerintah Kota Tangerang sudah dilakukan dengan baik salah satunya program PHBS (Perilaku Hidup Bersih dan Sehat) dilakukan secara tatap 
muka dan saling bersinergi dengan melakukan praktik secara langsung. Masyarakat RW.03 Kelurahan Karawaci-Kota Tangerang merasa komunikasi yang dilakukan Pemerintah Kota Tangerang lebih efektif jika dilakukan secara langsung atau tatap muka dibandingkan dengan menggunakan media digital karena tidak semua masyarakat tersebut bisa mengoperasikannya. Di sisi lain tentu pihak RT dan RW selaku tokoh lainnya terus melakukan sosialisasi penggunaan media digital seperti LAKSA, diharapkan dengan pemanfaatan media digital ini masyarakat dapat lebih mudah berkomunikasi terutama terkait pencemaran Sungai Cisadane. Pada dasarnya masyarakat sudah menyadari dan memahami setiap program yang dijalankan oleh Pemerintah dan DLH Kota Tangerang, namun dibutuhkan kerjasama lebih lagi antara masyarakat, pemerintah dan DLH Kota Tangerang agar dapat menghasilkan dampak seperti perubahan perilaku masyarakat yang signifikan. Masyarakat menjadi stakeholder penting dalam hal ini, pemberdayaan melalui kesadaran perilaku yang dilakukan pada setiap individu masyarakat sangat penting untuk terwujud.

Selanjutnya khalayak sasaran yang dituju sekaligus menjadi bagian dalam strategi komunikasi lingkungan ini adalah para pemilik pabrik, perusahaan swasta dan stakeholder lainnya. Di Kota Tangerang Selatan didominasi oleh perkantoran, jasa dan pemukiman sedangkan di Kota Tangerang terdapat beberapa pabrik yang masih beroperasi. Pada dasarnya sudah terdapat peraturan-peraturan yang digunakan untuk mengatur bagaimana pembuangan limbah dan sudah terjalin kerjasama antara pemerintah, pabrik, perkantoran, jasa, dan pemukiman untuk menangani limbah tersebut agar tidak mencemari Sungai Cisadane.

Pada Kota Tangerang Selatan, untuk unit usaha penghasil limbah dilakukan pengawasan secara berkala dan rutin. Selain pengawasan juga dilakukan uji petik sampling dan pemantauan kualitas air secara random di Kota Tangerang Selatan. Sedangkan untuk pemukiman rumah sudah menggunakan septic tank yang ramah lingkungan, seperti diketahui di Tangerang Selatan terdapat tiga pengembang yang mendominasi dan para pengembang tersebut telah melakukan pengelolaan limbah domestik menggunakan septic tank ramah lingkungan.

Di Kota Tangerang, untuk industri yang beroperasi juga sudah dilakukan pengawasan dan kunjungan industri yang dilakukan oleh Dinas Lingkungan Hidup (DLH) Kota Tangerang. Terdapat juga izin untuk pembuangan air limbah, namun perlu dilihat berapa kapasitas limbah yang diizinkan untuk dibuang, bagaimana kualitas air buangan tersebut, dan syarat lainnya. Untuk rekomendasi perizinan tetap ada Dinas Lingkungan Hidup (DLH) dan pihak DLH yang akan turun ke lapangan.

\section{Pengembangan Strategi Komunikasi Lingkungan Dalam Mengatasi Pencemaran Air Sungai Cisadane}

Untuk individu mencapai pemahaman mengenai tindakan dan pembicaraan satu sama lain dengan tujuan yang diarahkan, dan individu menghasilkan tindakan dan pembicaraan yang memungkinkan mencapai tujuan (Budyatna, 2015), sebagaimana dijelaskan dalam teori perencanaan komunikasi. Maka dapat dilakukan perencanaan komunikasi efektif yang dapat tertuang dalam 
pengembangan strategi komunikasi. Untuk mengembangkan strategi komunikasi lingkungan yang sudah dijalankan dalam mengatasi pencemaran air Sungai Cisadane, peneliti menggunakan fitur multilevel/multisektoral, fitur yang berorientasi pada proses dengan sinergitas dan fitur strategis (Flor \& Cangara, 2018), peneliti juga menambahkan beberapa langkah-langkah yang ditemukan oleh Wahyudin (Tan et al., 2019).

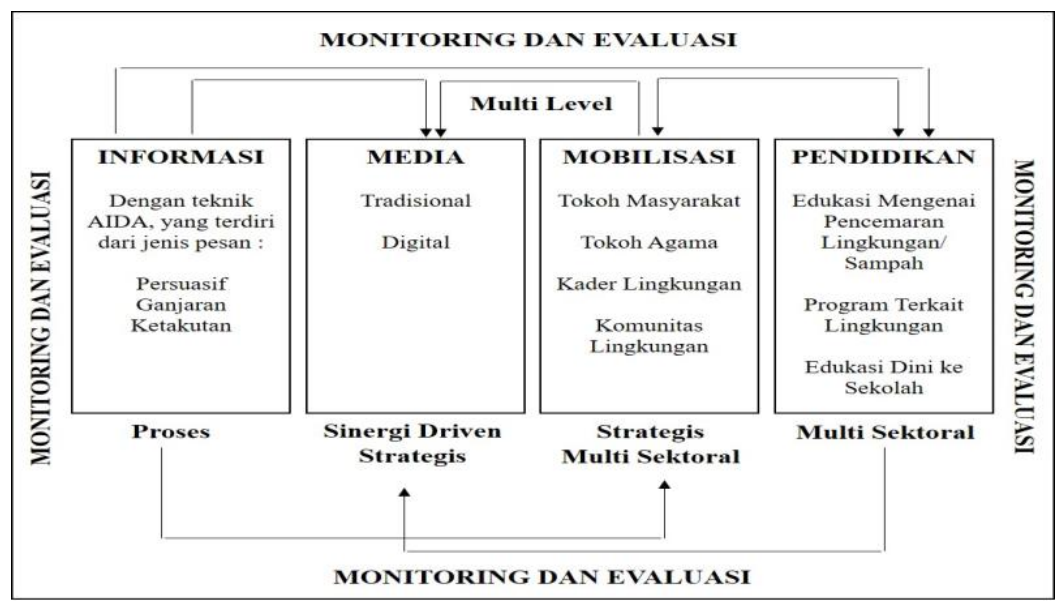

Gambar 4: Model Strategi Komunikasi Lingkungan Dalam Mengatasi Pencemaran Sungai Cisadane (Sumber : Olahan Peneliti)

Pada multi-level dengan komponen informasi, media, mobilisasi dan pendidikan, tetap melanjutkan apa yang sudah dilakukan baik dari Kota Tangerang maupun Kota Tangerang Selatan. Peneliti menambahkan beberapa hal seperti pada komponen informasi seperti menggunakan teknik pesan AIDA dan menambahkan jenis pesan imbauan ketakutan, di jenis pesan ini dirasa bisa berhasil untuk bisa menggerakan masyarakat untuk melakukan hal-hal yang dapat mengatasi pencemaran air di Sungai Cisadane.

Namun pesan bersifat imbauan ketakutan ini tidak perlu dibuat secara terus menerus, komunikator sebaiknya mengedepankan pesan bersifat ajakan dan ganjaran. Komponen media yang sudah dibentuk dan dilakukan menurut peneliti tetap perlu dipertahankan. Pada komponen mobilisasi, bisa dengan lebih menggerakan tokoh agama di sekitar masyarakat agar di setiap pertemuan ibadah, tokoh agama tersebut dapat membahas mengenai pentingnya menjaga kebersihan Sungai Cisadane. Di komponen pendidikan, edukasi dini yang dilakukan ke sekolah-sekolah dan edukasi serta pengawasan ke pabrik atau pengembang sudah baik begitupun dengan program-program yang sudah dijalankan, namun lebih baik ada program dan edukasi khusus mengenai Sungai Cisadane sehingga masyarakat, pabrik atau pengembang bisa lebih menyadari dan memiliki Sungai Cisadane. Pada fitur ini komunikasi lingkungan perlu dilakukan di semua tingkat masyarakat.

Berorientasi proses berarti mengadopsi proses AIDA yang diawali dengan kesadaran dan berakhir dengan tindakan, sehingga para komunikator dapat membuat pesan yang membuat masyarakat, dan stakeholder lainnya menjadi sadar kemudian membuat mereka tertarik untuk menimbulkan hasrat atau 
keinginan dan kemudian diakhiri dengan menghasilkan tindakan. Informasi ini bisa disampaikan dengan menggunakan media tradisional maupun digital, informasi bisa disampaikan sebagai bahan dalam melakukan mobilisasi oleh para komunikator, pembentukan opini maupun agenda sosial, dan bisa juga untuk sebagai bahan edukasi atau pendidikan. Pesan yang tertuang nantinya dalam program pemerintah maupun yang dibuat oleh komunitas juga turut perlu dilaksanakan dengan implementasi langsung dari penggagas program tersebut, hal ini perlu dilakukan untuk bisa memberikan efek seperti adanya masyarakat yang perilakunya berubah. Walaupun prosesnya tidak cepat, tetapi hal itu dapat tercapai dengan menjalankan komunikasi yang efektif kepada masyarakat.

Pada fitur sinergi driven dilakukan dengan mengerjakan bauran media. Dalam hal ini Pemerintah Kota dan DLH setiap kota perlu memilih media yang tepat dalam menyampaikan pesan pada masyarakat tertentu. Media digital diharapkan dapat lebih mudah dipakai oleh semua kalangan masyarakat, dan perlu diberikan sosialisasi sehingga bisa mengurangi mereka yang gagap teknologi. Media tradisional juga tetap perlu digunakan, karena media tradisional seperti televisi dan surat kabar dapat efektif digunakan untuk menyampaikan informasi mengenai lingkungan (Ahmad et al., 2015). Bauran media ini bisa dilakukan untuk menyampaikan informasi, membantu dalam melakukan mobilisasi maupun pendidikan, sehingga mengerjakan bauran media ini penting karena berkaitan dengan mobilisasi, pembentukan agenda sosial dan opini publik.

Multi-sektoral melibatkan beberapa khalayak atau mitra kerja sama yang mencakup stakeholder. Dalam fitur ini khalayak atau mitra yang digunakan adalah tokoh masyarakat seperti Ketua RT dan RW, kemudian tokoh agama, kader dan komunitas lingkungan. Dengan menuju ke semua tingkat masyarakat maka perlu dilibatkan orang-orang yang mampu menggerakan masyarakat, pabrik atau pengembang untuk bisa menjaga kebersihan Sungai Cisadane. Setiap orang yang ditunjuk tersebut harus mampu untuk melakukan mobilisasi dan pendidikan kepada masyarakat dan stakeholder baik menggunakan media tradisional seperti tatap muka secara intens maupun dengan menggunakan media digital. Selain itu kemampuan dalam melakukan mobilitas juga perlu diperhatikan. Maka pada multi-sektoral peneliti memasukan mobilisasi dan pendidikan karena pada bagian ini bisa melibatkan beberapa khalayak atau mitra dalam melakukan kerjasama. Pada pendidikan bisa menggunakan stakeholder seperti komunitas lingkungan ataupun narasumber ahli untuk bisa memberikan edukasi, memberikan sosialisasi, dan lainnya. Pemerintah Kota dan DLH setiap kota juga perlu memotivasi masyarakat untuk lebih memperhatikan dan menjaga kebersihan Sungai Cisadane. Pemerintah kota dan DLH juga dapat memobilisasi dengan melibatkan masyarakat dalam kegiatan-kegiatan yang berkaitan dalam mengatasi pencemaran air Sungai Cisadane, sehingga masyarakat mempunyai tanggung jawab yang lebih.

Dari sisi strategis dapat dilakukan melalui saluran interpersonal, kelompok, jaringan kelembagaan dan media. Peneliti memasukan tokoh masyarakat, tokoh agama, kader lingkungan dan komunitas lingkungan untuk melakukan komunikasi interpersonal maupun kelompok dan kelembagaan untuk bisa memberikan informasi dan pendidikan, termasuk media di dalamnya. Mereka 
merupakan pemain kunci tertentu dalam proses-proses sosial atau kelembagaan masyarakat. Strategi yang sudah disusun dapat dilakukan dengan memaksimalkan saluran interpersonal, kelompok, jaringan kelembagaan dari para tokoh-tokoh tersebut, komunitas lingkungan dan media.

Dalam menyusun strategi dan program tentunya perlu mengundang semua stakeholder, dari pertukaran pemikiran, dengar pendapat, penyusunan strategi dan program sampai pada pelaksanaannya semua stakeholder perlu dilibatkan sehingga para stakeholder tersebut mempunyai rasa memiliki dan bertanggung jawab atas apa yang sudah disusun. Selain itu penting dalam suatu pelaksanaan adalah adanya monitoring atau pemantauan secara rutin guna menilai apakah kegiatan tersebut berjalan sesuai dengan yang disusun atau perlu dilakukan perbaikan, sehingga saat dilakukan evaluasi terlihat hasil dari pelaksanaan kegiatan yang dijalankan tersebut terjadi perubahan dan progress signifikan atau sebaliknya. Evaluasi juga berguna untuk mengkaji ulang situasi dan masalah yang terjadi, sehingga ke depan bisa membuat strategi ataupun hal lainnya yang lebih baik lagi dan sesuai dengan situasi dan masalah yang dihadapi. Diperlukan juga adanya sinergi antara pemerintah provinsi, kota maupun DLH dan dinas lainnya yang terkait pada setiap daerah yang dilintasi oleh Sungai Cisadane, kerjasama tersebut tentu diharapkan dapat mengatasi pencemaran air Sungai Cisadane. Tentunya model strategi komunikasi lingkungan ini masih dapat dilengkapi lagi dengan meninjau dari komponen-komponen komunikasi dan hal lainnya yang bisa membuat model ini menjadi lebih baik lagi dan relevan.

\section{Simpulan}

Berdasarkan hasil penelitian di atas, maka peneliti mengambil kesimpulan bahwa strategi komunikasi lingkungan yang sudah dilakukan oleh pemerintah Kota dan DLH Kota Tangerang dan Kota Tangerang Selatan dalam mengatasi pencemaran air Sungai Cisadane pada dasarnya sudah berjalan dengan baik. Agar lebih baik lagi maka diperlukan lagi konsistensi dalam pengelolaan strategi komunikasi lingkungan tersebut. Kesimpulan berikutnya terkait dengan pengembangan strategi komunikasi lingkungan, peneliti menambahkan beberapa hal pada strategi yang sudah dijalankan oleh Pemerintah Kota dan Dinas Lingkungan Hidup Kota Tangerang dan Kota Tangerang Selatan, seperti pada bagian informasi yang masuk dalam multi level dan proses, bagian mobilisasi yang menjadi bagian strategis dan multi sektoral. Dalam mengembangkan strategi komunikasi lingkungan peneliti menyarankan kepada Pemerintah Kota dan DLH untuk khusus memberikan edukasi mengenai pencemaran lingkungan di Sungai Cisadane ataupun mengenai sampah. Dalam pelaksanaan strategi ini juga dibutuhkan monitoring atau pengawasan agar berjalan dengan baik dan perlu dilakukan evaluasi sehingga terdapat strategi yang lebih baik lagi dan relevan serta perlu adanya sinergi antara pemerintah provinsi, kota maupun DLH dan dinas lainnya yang terkait pada setiap daerah yang dilintasi oleh Sungai Cisadane. 


\section{Ucapan Terima Kasih}

Peneliti mengucapkan terima kasih kepada Kementerian Riset dan Teknologi / Badan Riset dan Inovasi Nasional (RISTEK-BRIN) yang telah mendanai penelitian ini dan setiap narasumber serta masyarakat RW.03 Kelurahan Karawaci yang memberikan informasi dalam penelitian ini. Peneliti juga mengucapkan terima kasih kepada editor Jurnal Komunikasi Universitas Tarumanagara yang telah memberikan masukan bagi penelitian ini.

\section{Daftar Pustaka}

Ahmad, J., Md. Noor, S., \& Ismail, N. (2015). Investigating students' environmental knowledge, attitude,practice and communication. Asian Social Science. https://doi.org/10.5539/ass.v11n16p284

Astuti, S. D., Putri, I. P., \& Ali, D. S. F. (2016). Strategi Komunikasi Program Internet Sehat Dan Aman Kementerian Komunikasi Dan Informatika Republik Indonesia (Studi Kasus Evaluasi Program Incakap Tahun 2015). Jurnal Komunikasi, 8(1), 25-35.

Beritasatu.tv. (2014). Air Sungai Cisadane Tercemar Limbah Pabrik. http://www.beritasatu.tv/news/air-sungai-cisadane-tercemar-limbahpabrik/

Brulle, R. J. (2010). From environmental campaigns to advancing the public dialog: Environmental communication for civic engagement. Environmental Communication, 42-98. https://doi.org/10.1080/17524030903522397

Budyatna, M. (2015). Teori-Teori Mengenai Komunikasi Antar-Pribadi. Prenadamedia Group.

Cangara, H. (2013). Perencanaan dan Strategi Komunikasi. PT. RajaGrafindo Persada.

Dawud, M., Namara, I., Chayati, N., \& Taqwa, F. M. L. (2016). Analisis Sistem Pengendalian Pencemaran Air Sungai Cisadane Kota Tangerang Berbasis Masyarakat. Jurnal.Umj.Ac.Id/Index.Php/Semnastek, 1-8.

Fatah, D. (2018). KLHK Jelaskan Penanganan Pencemaran Sungai Citarum, Cisadane dan Ciujung. https://indopos.co.id/read/2018/11/23/156492/klhk-jelaskan-penangananpencemaran-sungai-citarum-cisadane-dan-ciujung/

Fida, W. N., Unde, A. A., \& Arianto, A. (2019). Strategi Komunikasi Interpersonal Orang Tua Terhadap Anak Remaja Dalam Menghadapi Pergaulan Bebas Di Negeri Tulehu Kabupaten Maluku Tengah. II(I), 2230.

Flor, A., \& Cangara, H. (2018). Komunikasi Lingkungan: Penanganan KasusKasus Lingkungan Melalui Strategi Komunikasi. Prenadamedia Group.

Frianda, V., Hairunnisa, H., \& Ghufron, G. (2018). Strategi Komunikasi Lembaga Swadaya Masyarakat Gerakan Memungut Sehelai Sampah (LSM GMSS) Dalam Mengkampanyekan Larangan Membuang Sampah Di Sungai Karang Mumus Samarinda. EJournal Ilmu Komunikasi, 6(2), 43-57. 
Imran, H. A. (2015). Penelitian Komunikasi Pendekatan Kualitatif Berbasis Teks Communication Research Of Text-Based Qualitative Approach. Jurnal Studi Komunikasi Dan Media, 19(1), 129-139.

Kriyantono, R. (2012). Teknik Praktis Riset Komunikasi (6th ed.). Prenadamedia Group.

Kurniawan, H. (2019). Sampah TPA Cipeucang Longsor, Sungai Cisadane Tercemar. https://metro.sindonews.com/read/1381929/170/sampah-tpacipeucang-longsor-sungai-cisadane-tercemar-1551096096

Lestari, P., Paripurno, E. T., Kusumayudha, S. B., \& Ramadhaniyanto, B. (2016). Komunikasi Lingkungan untuk Mitigasi Bencana Erupsi Gunung $\begin{array}{llll}\text { Sinabung. Jurnal } & \text { ASPIKOM, } & \end{array}$ https://doi.org/10.24329/aspikom.v3i1.98

Mishra, L. (2016). Focus Group Discussion in Qualitative Research. TechnoLearn: An International Journal of Educational Technology. https://doi.org/10.5958/2249-5223.2016.00001.2

Peraturan Pemerintah Republik Indonesia Nomor 38 Tahun 2011 Tentang Sungai, (2011).

Siahaan, R., Indrawan, A., Soedharma, D., \& Prasetyo, L. B. (2011). Kualitas Air Sungai Cisadane , Jawa Barat - Banten (Water Quality of Cisadane River , West Java - Banten). Jurnal Imliah Sains, 11(2).

Situmeang, I. V. O. (2020). Strategi Komunikasi Pariwisata: Menciptakan Seminyak Menjadi Top of Mind Tujuan Wisata Di Bali. Scriptura, 10(1), 43-52. https://doi.org/10.9744/scriptura.10.1.43-52

Tan, A. M., Sarmiati, S., \& Elfitra, E. (2019). Komunikasi Lingkungan Sebagai Upaya Pencegahan Kerusakan Lingkungan Kawasan Wisata (Studi Deskriptif Pada Pemerintah Kabupaten Pesisir Selatan Di Kawasan Wisata Mandeh). Komunikasi, XIII(02), 97-108.

Tunggala, S., \& Saadjad, K. A. (2019). Strategi Komunikasi pada Dinas Kebudayaan dan Pariwisata dalam Mempromosikan Objek Wisata Kabupaten Banggai. Jurnal Komunikasi, 11(2), 197-212. https://doi.org/10.24912/jk.v11i2.2714 